\title{
Prediction of postoperative lung function after major lung resection for lung cancer using volumetric computed tomography
}

\author{
Lucía Fernández-Rodríguez, MD, ${ }^{\mathrm{a}}$ Isabel Torres, MD, ${ }^{\mathrm{a}}$ Delia Romera, MD, ${ }^{\mathrm{b}}$ Raúl Galera, MD, ${ }^{\mathrm{b}, \mathrm{c}}$ \\ Raquel Casitas, MD, ${ }^{\mathrm{b}, \mathrm{c}}$ Elisabet Martínez-Cerón, MD, ${ }^{\mathrm{b}, \mathrm{c}}$ Prudencio Díaz-Agero, MD, ${ }^{\mathrm{d}}$ \\ Cristina Utrilla, MD, ${ }^{\mathrm{a}}$ and Francisco García-Río, $\mathrm{MD}^{\mathrm{b}, \mathrm{c}, \mathrm{e}}$
}

\section{ABSTRACT}

Objectives: The study objectives were to assess the accuracy of volumetric computed tomography to predict postoperative lung function in patients with lung cancer in relation to anatomic segments counting and perfusion scintigraphy, to generate specific predictive equations for each functional parameter, and to evaluate accuracy and precision of these in a validation cohort.

Methods: We assessed pulmonary functions preoperatively and 3 to 4 months postoperatively after lung resection for lung cancer $(\mathrm{n}=114)$. Absolute and relative lung volumes (total and upper/middle/lower) were determined using volumetric software analysis for staging thoracic computed tomography scans. Predicted postoperative function was calculated by segments counting, scintigraphy, and volumetric computed tomography.

Results: Volumetric computed tomography achieves a higher correlation and precision with measured postoperative lung function than segments counting or scintigraphy (correlation and intraclass correlation coefficients, 0.779-0.969 and $0.776-0.969 ; 0.573-0.887$ and $0.552-0.882$; and $0.578-0.834$ and $0.532-0.815$, respectively), as well as greater accuracy, determined by narrower agreement coefficients for forced vital capacity, forced expiratory volume in 1 second, lung diffusing capacity, and peak oxygen uptake. After validation in an independent cohort $(n=43)$, adjusted linear regression including volumetric estimation of decreased postoperative ventilation for postoperative lung function parameters explains $98 \%$ to $99 \%$ of variance.

Conclusions: Volumetric computed tomography is a reliable and accurate method to predict postoperative lung function in patients undergoing lung resection that provides better accuracy than conventional procedures. Because lung computed tomography is systematically performed in the staging of patients with suspected lung cancer, this volumetric analysis might simultaneously provide the information necessary to evaluate operability. (J Thorac Cardiovasc Surg 2018;156:2297-308)

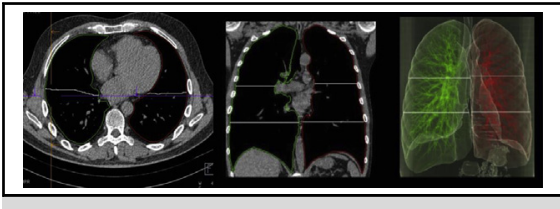

Segmentation of the thorax in a CT scan with a volumetric representation of the lung areas.

\section{Central Message}

Volumetric CT is an accurate and precise method to predict postoperative lung function in patients undergoing lung resection, with better accuracy than conventional procedures.

\section{Perspective}

Preoperative evaluation is essential to define the immediate perioperative and the long-term risks of pulmonary disability associated with surgical loss of lung parenchyma. Recent advances in technology, multidetector row $\mathrm{CT}$, and simulation software allow for 3-dimensional lung models to be reconstructed, providing more accurate estimations of the different lung volumes than conventional methods.

See Editorial Commentary page 2309.

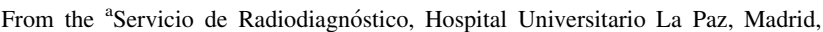
Spain; 'bervicio de Neumología, Hospital Universitario La Paz, IdiPAZ, Madrid, Spain; ${ }^{\mathrm{c} C I B E R}$ de Enfermedades Respiratorias, Madrid, Spain; ${ }^{\mathrm{d}}$ Servicio de Cirugía Torácica, Hospital Universitario La Paz, IdiPAZ, Madrid, Spain; and ${ }^{\mathrm{e}}$ Facultad de Medicina, Universidad Autónoma de Madrid, Madrid, Spain.

Funded by the Fundación para la Investigación Biomédica Hospital Universitario La Paz (FIBHULP), Spain [2/2011]

Received for publication Aug 5, 2017; revisions received June 15, 2018; accepted for publication July 2, 2018; available ahead of print Sept 6, 2018.

Address for reprints: Francisco García-Río, MD, Servicio de Neumología, Hospital

Universitario LaPaz, IdiPAZ, Paseo de la Castellana, 261, Madrid 28046, Spain

(E-mail: fgr01m@gmail.com).

$0022-5223 / \$ 36.00$

Copyright (c) 2018 by The American Association for Thoracic Surgery

https://doi.org/10.1016/j.jtcvs.2018.07.040
}

Lung resection is the primary treatment option for patients with early-stage non-small cell lung cancer. ${ }^{1}$ According to current guidelines, preoperative physiologic assessment should include the measurement of forced expiratory volume in 1 second $\left(\mathrm{FEV}_{1}\right)$ and diffusing capacity for

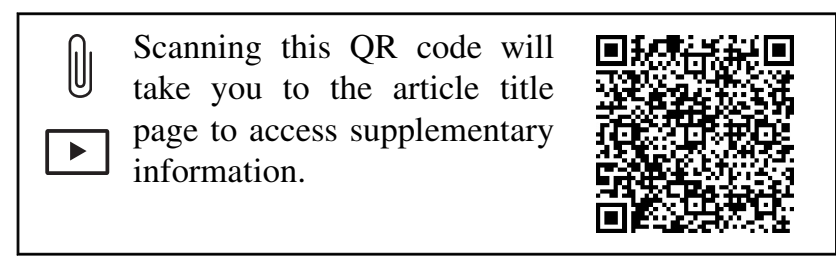




$$
\begin{aligned}
& \text { Abbreviations and Acronyms } \\
& \text { ASC }=\text { anatomic segments counting } \\
& \mathrm{CT}=\text { computed tomography } \\
& \mathrm{DLCO}=\text { diffusing capacity for carbon monoxide } \\
& \mathrm{FEV}_{1}=\text { forced expiratory volume in } 1 \text { second } \\
& \mathrm{FVC}=\text { forced vital capacity } \\
& \text { ppo }=\text { predicted postoperative } \\
& \mathrm{PS} \quad \text { perfusion scintigraphy } \\
& \mathrm{VO}_{2}=\text { oxygen uptake }
\end{aligned}
$$

carbon monoxide (DLCO), as well as peak oxygen uptake $\left(\mathrm{VO}_{2}\right)$ when $\mathrm{FEV}_{1}$ or DLCO is lower than $80 \%$ predicted. $^{2}$ Moreover, it is recommended that predicted postoperative (ppo) lung function be calculated, because it is a standard measure for assessing the potential risks of major lung resection $^{2-4}$ and is a more powerful predictor than preoperative values. $^{5}$

Commonly used methods for predicting postlung resection function include conventional lung perfusion scintigraphy (PS) and an anatomic method based on counting the number of functional segments to be removed before lobectomy. ${ }^{2,6,7}$ However, the accuracy of these methods varies according to the type of resection performed. ${ }^{2,8}$ Among the different alternatives proposed, ${ }^{9-17}$ chest computed tomography (CT) is particularly interesting, because it is mandatory for the staging of any patient with lung cancer and therefore might provide simultaneous evaluation of operability. With recent advances in technology, multidetector row CT and simulation software (which complete the densitometry analysis with a volumetric analysis) allow for 3-dimensional lung models to be reconstructed, providing more accurate estimations of the different lung volumes. ${ }^{18,19}$

The aims of this study were (1) to compare volumetric CT with traditional methods to predict several postoperative lung parameters; (2) to develop new equations for predicting these using volumetric $\mathrm{CT}$, based on measured pulmonary function and pre- and postpulmonary resection variables; and (3) to evaluate the accuracy and precision of these equations in a validation cohort operated on subsequent to the equation development cohort.

\section{MATERIAL AND METHODS \\ Study Subjects}

Patients with lung cancer or other intrathoracic malignancies, considered candidates for lung resection and referred to estimate postoperative lung function, were recruited from La Paz Hospital between 2009 and 2014. Operability assessment was performed by applying the Wyser algorithm, ${ }^{20}$ which has been validated in our setting. ${ }^{21}$ For each patient, the most favorable postoperative lung function predicted by anatomic segment counting or PS was considered. Excluded from the study were patients who had undergone any type of prior thoracic surgery, those with contraindications for lung function testing, or those who had died within 3 months after lung resection. Patients operated on between 2009 and 2013 were considered the cohort to generate multivariable regression equations for ppo lung function values, and patients operated on in 2014 constituted the validation cohort of said equations. Bronchial tumors were staged according to the seventh edition of the International System for Staging Lung Cancer. $^{22}$ Patients of the development cohort underwent preoperative lung CT and PS, as well as pulmonary function tests before and 3 to 4 months after surgery. In the validation cohort, only lung CT and pulmonary function tests were performed. All subjects provided informed consent, and the study was approved by the local Human Research Ethics Committee (PI-1266).

\section{Computed Tomography Image Acquisition and Postprocessing}

CT performed in the lung cancer diagnosis and staging process was used. Subjects were scanned in the supine position from the lung apex to the base of the chest at withheld full inspiration. All image data were obtained with a 16-row multidetector CT scanner (Somatom Emotion 16, Siemens, Erlangen, Germany) with the following parameters: slice width, $0.3 \mathrm{~mm}$; reconstruction increment, $0.5 \mathrm{~mm}$; collimation, $16 \times 0.75 \mathrm{~mm}$; pitch, 0.8; slice collimation, $0.6 \mathrm{~mm}$; voltage, $120 \mathrm{kVp}$; reference tube current-time, $160 \mathrm{mAs}$; and rotation time, 0.6 seconds. Routine matrix clinical images were reconstructed with B41 kernel to assessment of soft tissues and high-resolution B90 kernel to assessment of lung parenchyma.

Postprocessing was performed in an independent reconstruction console (Leonardo, Siemens) using a semiautomatic analysis program (syngo InSpace4D, Siemens), which performs a quantitative evaluation of the attenuation of lung parenchyma. The software automatically performs a 3-dimensional segmentation of the lung and, based on the pulmonary reference points and the attenuation thresholds, allows the automatic 3-dimensional quantification of the volume and relative volume percentages of each lung, stratifying the results by lung thirds (upper, middle, and lower) (Figure E1).

\section{Lung Function Tests}

Evaluations were performed before and 3 to 4 months after lung resection surgery using the same procedures and equipment. Spirometry and carbon monoxide diffusion tests were performed according to American Thoracic Society/European Respiratory Society guidelines by means of a MasterLab Pro system (Vyasis Healthcare, Hoechberg, Germany). Spirometric parameters used for the preoperative evaluation were obtained 20 minutes after inhalation of $400 \mu \mathrm{g}$ of salbutamol, whereas DLCO was corrected for the patients' hemoglobin values (obtained within a maximum period of 72 hours). Reference values of Quanjer and Cotes were used. $^{23,24}$

In patients with a $\mathrm{FEV}_{1}$ or DLCO less than $80 \%$ predicted, a symptomlimited incremental exercise test was performed on an electromagnetically braked cycle-ergometer, using a 1-minute step protocol at $15 \mathrm{~W} / \mathrm{min}$ according to American Thoracic Society/American College of Chest Physicians guidelines. Ventilation and pulmonary gas exchange were measured breath by breath with an Oxycon Alpha exercise system (Vyasis Healthcare, Conshohocken, Pa). Data were averaged every 10 seconds to obtain $\mathrm{VO}_{2}$ peak. The predicted values of Jones were used for the exercise measurements. ${ }^{25}$

\section{Lung Perfusion Scintigraphy}

Patients received an intravenous injection of $185 \mathrm{MBq}(5 \mathrm{mCi})$ macroaggregated albumin labeled with technetium-99 in the supine position, and a double-head Axis 2 gamma camera (Picker, Fort Myers, Fla) was used with a low-energy high-resolution collimator, $256 \times 256$ matrix, $140 \mathrm{keV}$, and a $15 \%$ energy window. Five minutes after radiotracer injection, static images of the lungs with 500,000 counts were obtained in 


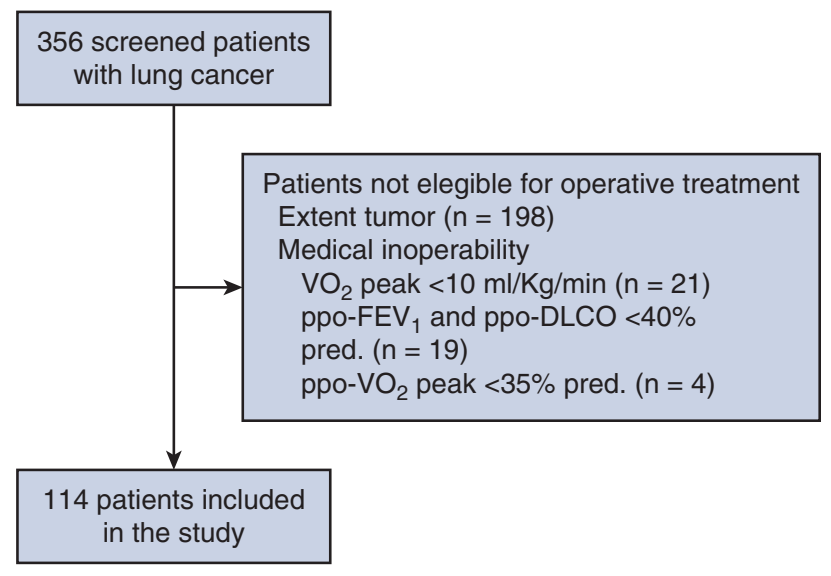

FIGURE 1. CONSORT diagram of the selection process of the development cohort. $D L C O$, Lung diffusion capacity for carbon monoxide; $F E V_{1}$, forced expiratory volume in 1 second; ppo, predicted postoperative; $\mathrm{VO}_{2}$, oxygen uptake.

the anterior, posterior, both posterior oblique, and both anterior oblique projections. Semiquantitative analyses of planar and tomographic images were performed with the Odyssey FX 810 workstation (Marconi Medical System, Cleveland, Ohio). Regions of interest were drawn in the anterior and posterior projections around the entire lung, and each lung was divided into thirds to create superior, middle, and inferior regions of interest. The percentages of the function for each region were calculated by the geometric mean of the anterior and posterior counts.

\section{Prediction of Postoperative Lung Function}

The ppo lung function was computed by 3 methods: anatomic functional segments counting (ASC), PS, and volumetric CT. Predictions of postoperative lung function based on functional segments were based on the following equation: ppo value $=$ preoperative value $\times[1-(\mathrm{S}-\mathrm{N}) /$ $(19-\mathrm{N})$ ], where $\mathrm{S}$ is the number of resected segments, $\mathrm{N}$ is the number of obstructed or consolidated segments resected, and 19 indicates the total number of segments in both lungs. On the basis of the findings of lung $\mathrm{CT}$ and bronchoscopy, $\mathrm{N}$ was counted as 1 for a segment with a narrowing greater than $75 \%$ or as 0.5 for a segment with $50 \%$ to $75 \%$ stenosis. ${ }^{26}$ The number of segments resected was assigned as 3 for right upper lobectomy, 2 for middle lobectomy, 5 for right lower lobectomy, 5 for left upper lobectomy, 4 for left lower lobectomy, and the sum corresponding for each type of bilobectomy or pneumonectomy. ${ }^{2}$ In the methods based on PS or volumetric CT, the percentage of perfusion or the percentage of volume in each zone/lobe was determined in relation to the perfusion or volume of both lungs. Thus, the following equation was used: ppo value $=$ preoperative value $\times(1-$ functional contribution of perfusion or ventilation of the region to be resected). ${ }^{16}$ Calculations were made for both absolute and percent predicted values of ppo-FEV ${ }_{1}$, ppo-forced vital capacity (FVC), ppo-DLCO, and ppo- $\mathrm{VO}_{2}$ peak.

\section{Statistical Analysis}

Sample size calculation was based on an agreement coefficient between

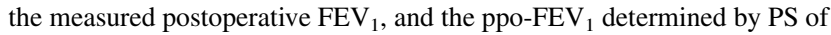
$0.04 \pm 0.231 .{ }^{16}$ On the basis of a 2-tailed test with an alpha $=0.05$ and beta $=0.20$, the sample size necessary to detect a difference of at least 0.061 using the volumetric CT method was 114 participants.

Data are summarized as mean \pm standard deviation for continuous variables, and frequencies (percentages) are used for categoric variables. The normality of the distribution of variables was tested using the Kolmogorov-Smirnov test. Relationships between predicted and measured
TABLE 1. Patient characteristics*

\begin{tabular}{|c|c|c|}
\hline Parameter & Development cohort & Validation cohort \\
\hline $\mathrm{n}$ & 114 & 43 \\
\hline Men, n (\%) & $87(72 \%)$ & $30(70 \%)$ \\
\hline Age, y & $63 \pm 12$ & $66 \pm 11$ \\
\hline BMI, $\mathrm{kg} / \mathrm{m}^{2}$ & $26.5 \pm 4.3$ & $26.0 \pm 3.6$ \\
\hline Current smokers, n (\%) & $33(32 \%)$ & $15(35 \%)$ \\
\hline COPD diagnosis, $\mathrm{n}(\%)$ & $45(40 \%)$ & $20(47 \%)$ \\
\hline $\begin{array}{l}\text { Histology } \\
\text { Adenocarcinoma } \\
\text { Squamous } \\
\text { NSCLC, not specified } \\
\text { Other neoplasms }\end{array}$ & $\begin{array}{l}59(52 \%) \\
24(21 \%) \\
11(10 \%) \\
20(18 \%)\end{array}$ & $\begin{array}{c}26(61 \%) \\
10(23 \%) \\
3(7 \%) \\
4(9 \%)\end{array}$ \\
\hline $\begin{array}{l}\text { Final pathologic stage } \\
\text { O, I } \\
\text { II } \\
\text { III }\end{array}$ & $\begin{array}{l}53(46 \%) \\
24(21 \%) \\
20(18 \%)\end{array}$ & $\begin{array}{c}28(65 \%) \\
9(21 \%) \\
3(7 \%)\end{array}$ \\
\hline $\begin{array}{l}\text { Pulmonary resection } \\
\text { Pneumonectomy } \\
\text { Bilobectomy } \\
\text { Lobectomy }\end{array}$ & $\begin{array}{l}17(15 \%) \\
13(11 \%) \\
84(74 \%)\end{array}$ & $\begin{array}{c}3(7 \%) \\
5(12 \%) \\
35(81 \%)\end{array}$ \\
\hline $\begin{array}{l}\text { Baseline lung function } \\
\text { FVC, 1 } \\
\text { FVC, \% predicted } \\
\mathrm{FEV}_{1}, 1 \\
\mathrm{FEV}_{1}, \% \text { predicted } \\
\mathrm{FEV}_{1} / \mathrm{FVC} \\
\mathrm{DLCO}, \mathrm{mm} / \mathrm{min} / \mathrm{kPa} \\
\mathrm{DLCO}, \% \text { predicted } \\
\mathrm{VO}_{2} \text { peak, } \mathrm{mL} / \mathrm{kg} / \mathrm{min} \dagger \\
\mathrm{VO}_{2} \text { peak, \% predicted } \dagger\end{array}$ & $\begin{aligned} 3.32 & \pm 0.92 \\
97 & \pm 19 \\
2.33 & \pm 0.73 \\
86 & \pm 19 \\
0.70 & \pm 0.11 \\
6.79 & \pm 0.70 \\
83 & \pm 17 \\
18.8 & \pm 2.6 \\
80 & \pm 29\end{aligned}$ & $\begin{array}{c}3.39 \pm 0.85 \\
118 \pm 29 \\
2.35 \pm 0.69 \\
98 \pm 22 \\
0.70 \pm 0.14 \\
6.66 \pm 1.62 \\
84 \pm 17 \\
17.0 \pm 3.1 \\
83 \pm 27\end{array}$ \\
\hline $\begin{array}{l}\text { Postoperative lung function } \\
\text { FVC, } 1 \\
\text { FVC, } \% \text { predicted } \\
\mathrm{FEV}_{1}, 1 \\
\mathrm{FEV}_{1}, \% \text { predicted } \\
\mathrm{FEV}_{1} / \mathrm{FVC} \\
\mathrm{DLCO}, \mathrm{mm} / \mathrm{min} / \mathrm{kPa} \\
\mathrm{DLCO}, \% \text { predicted } \\
\mathrm{VO}_{2} \text { peak, } \mathrm{mL} / \mathrm{kg} / \mathrm{min} \dagger \\
\mathrm{VO}_{2} \text { peak, \% predicted } \dagger \\
\end{array}$ & $\begin{aligned} 2.59 & \pm 0.78 \\
76 & \pm 18 \\
1.80 & \pm 0.60 \\
66 & \pm 17 \\
0.70 & \pm 0.10 \\
5.26 & \pm 1.55 \\
64 & \pm 17 \\
14.8 & \pm 2.7 \\
63 & \pm 24\end{aligned}$ & $\begin{aligned} 2.96 & \pm 0.98 \\
89 & \pm 20 \\
1.92 & \pm 0.71 \\
74 & \pm 18 \\
0.67 & \pm 0.15 \\
5.26 & \pm 1.44 \\
67 & \pm 15 \\
12.9 & \pm 2.4 \\
64 & \pm 24\end{aligned}$ \\
\hline
\end{tabular}

$B M I$, Body mass index; $C O P D$, chronic obstructive pulmonary disease; $N S C L C$, non-small cell lung cancer; $F V C$, forced vital capacity; $F E V_{l}$, forced expiratory volume in 1 second; $D L C O$, lung diffusion capacity for carbon monoxide; $V O_{2}$, oxygen uptake. $*$ Values are mean \pm standard deviation or percentage. $\dagger \mathrm{VO}_{2}$ peak was determined in 58 patients in the development cohort and in 21 patients in the validation cohort.

postoperative values for each lung function parameter were calculated with Pearson's correlation, and reliability was assessed through intraclass correlation coefficients for single measures, using a 2-way mixed model and absolute agreement. Limits of agreement between measured and ppo lung function values were analyzed by means of Bland-Altman analysis. ${ }^{27}$

In the development of multivariable predictive equations for postoperative lung function, sex, age, height, weight, body mass index, and body surface area were included as independent variables, along with the preoperative lung function, the time since surgery to measurement 
TABLE 2. Comparison of measured postoperative lung function values with the estimated values by the 3 evaluated methods*

\begin{tabular}{|c|c|c|c|c|c|}
\hline Parameter & Measured & Anatomic segments counting & PS & Volumetric CT & $P$ value \\
\hline FVC, 1 & $2.59 \pm 0.78$ & $2.49 \pm 0.81$ & $2.44 \pm 0.87$ & $2.56 \pm 0.77$ & .475 \\
\hline FVC, $\%$ predicted & $76 \pm 18$ & $73 \pm 18$ & $71 \pm 21$ & $75 \pm 17$ & .234 \\
\hline $\mathrm{FEV}_{1}, 1$ & $1.80 \pm 0.60$ & $1.75 \pm 0.63$ & $1.70 \pm 0.64$ & $1.79 \pm 0.61$ & .616 \\
\hline $\mathrm{FEV}_{1}, \%$ predicted & $66 \pm 17$ & $64 \pm 17$ & $63 \pm 19$ & $66 \pm 17$ & .359 \\
\hline $\mathrm{FEV}_{1} / \mathrm{FVC}$ & $0.70 \pm 0.11$ & $0.71 \pm 0.11$ & $0.70 \pm 0.11$ & $0.70 \pm 0.11$ & .989 \\
\hline $\mathrm{DLCO}, \mathrm{mmol} / \mathrm{min} / \mathrm{kPa}$ & $5.26 \pm 1.55$ & $5.07 \pm 1.48$ & $4.99 \pm 1.66$ & $5.23 \pm 1.48$ & .489 \\
\hline DLCO, $\%$ predicted & $64 \pm 17$ & $62 \pm 15$ & $61 \pm 19$ & $64 \pm 16$ & .348 \\
\hline $\mathrm{VO}_{2}$ peak, $\mathrm{mL} / \mathrm{kg} / \mathrm{min}$ & $14.8 \pm 2.7$ & $14.1 \pm 2.3$ & $13.7 \pm 3.4$ & $14.4 \pm 2.7$ & .213 \\
\hline $\mathrm{VO}_{2}$ peak, $\%$ predicted & $63 \pm 24$ & $60 \pm 23$ & $58 \pm 23$ & $61 \pm 23$ & .679 \\
\hline
\end{tabular}

Comparisons between groups by analysis of variance. $P S$, Perfusion scintigraphy; $C T$, computed tomography; $F V C$, forced vital capacity; $F E V_{1}$, forced expiratory volume in 1 second; $D L C O$, lung diffusing capacity of carbon monoxide; $\mathrm{VO}_{2}$, oxygen uptake. ${ }^{*}$ Data are mean \pm standard deviation.

of postoperative lung function, and the conversion factor previously described for each evaluation method (ASC, PS, and volumetric CT). The effect of logarithmic and square root transformations of pulmonary function parameters before modeling was also examined. Various regression models (linear, logarithmic, inverse, quadratic, cubic, growth, and exponential) were applied to the series to explain the postoperative lung function values. In the end, we selected a low-order polynomial model because the other tested models did not appear to offer any further significant statistical advantages. In the multiple linear regression analysis, the stepwise method was used to include or remove 1 independent variable at each step, based on the probability of $F$ (entry: 0.05; removal: 0.10 ). Other aspects explored included the residual standard deviation, changes in the distribution of the residuals, and homogeneity of the variance over the predictors. The assumptions of linearity and distributional normality were confirmed for all variables. Histogram of residuals and normal probability plot of residuals were used to test for normality. Homoscedasticity was explored by scatter plots of the standardized residuals on the standardized predicted values and by Levene's test for equality of variances. When heteroscedasticity was suspected, regression coefficients were computed using weighted least squares. In all regression models, multicollinearity was checked by the determination of the variance inflation factor less than 3 for each predictor. All analyses were performed using SPSS 13.0 software (SPSS Inc, Chicago, Ill).

\section{RESULTS}

A total of 114 patients were included in the development cohort (Figure 1) and 43 patients in the validation cohort. All patients were available for the analysis, and postoperative lung function was examined $13 \pm 3$ weeks after surgery. General patient characteristics are presented in Table 1.

Relationships between the predicted and measured postoperative values (Table 2) are shown in Figure 2, as well as the reliability of the 3 methods for predicting postoperative lung function. For all lung function parameters, correlation coefficients for the ASC and PS were relatively similar, although lower than for the volumetric CT (Table E1). Intraclass correlation coefficients showed a similar tendency. Given that its intraclass correlation coefficient is greater than 0.90 , volumetric $\mathrm{CT}$ reaches excellent reliability levels to predict postoperative FVC, $\mathrm{FEV}_{1}$, DLCO, and $\mathrm{VO}_{2}$ peak and is clearly superior to the other 2 methods.
Agreement between measured and ppo values by the 3 methods is shown in Figures 3 and E2. Volumetric CT reaches better agreement with measured postoperative lung function than ASC or PS for FVC (agreement limits: -0.42 to 0.35 vs -1.05 to 0.85 vs -1.21 to 0.901 , respectively), $\mathrm{FEV}_{1}$ ( -0.34 to 0.32 vs -0.75 to 0.65 vs -0.88 to 0.681$)$, DLCO ( -1.25 to 1.18 vs -2.41 to 2.02 vs -2.77 to $2.23 \mathrm{mmol} / \mathrm{min} / \mathrm{kPa}$ ), or $\mathrm{VO}_{2}$ peak ( -0.4 to 3.2 vs -5.3 to 4.0 vs -6.9 to $4.7 \mathrm{~mL} / \mathrm{kg} / \mathrm{min}$ ). When analyzed according to the extent of resection, limits of agreement showed a similar trend, both for pneumonectomies or bilobectomies and for lobectomies, and were always narrower for the estimates made by volumetric CT than by ASC or PS (Table E2). Likewise, no significant differences were detected in the agreement limits between patients with normal spirometry or airflow limitation $\left(\mathrm{FEV}_{1} / \mathrm{FVC}<0.7\right)$, although they were also narrower when the ppo values were determined by volumetric CT than by the other 2 methods (Table E3).

Table 3 shows the parameters related with the postoperative lung function in the univariable regression and the output for each variable included in the final multivariable regression model. The multivariable regression equations developed to calculate the ppo lung function are presented in Table 4. Of the 3 evaluated methods, the models only retained the correction factor provided by the volumetric CT. It is interesting to note that the models generated for the 4 pulmonary function parameters evaluated account for more than $97 \%$ of the explained variance in each variable.

Finally, the multivariable equations for the prediction of postoperative lung function were tested in the validation cohort (Figure 4). As shown in Figure 5 and Table E4, Pearson correlation coefficients, intraclass correlation coefficients, and limits of agreement were similar to those reached in the development cohort, which confirms the validation of these equations in a new group of patients. 

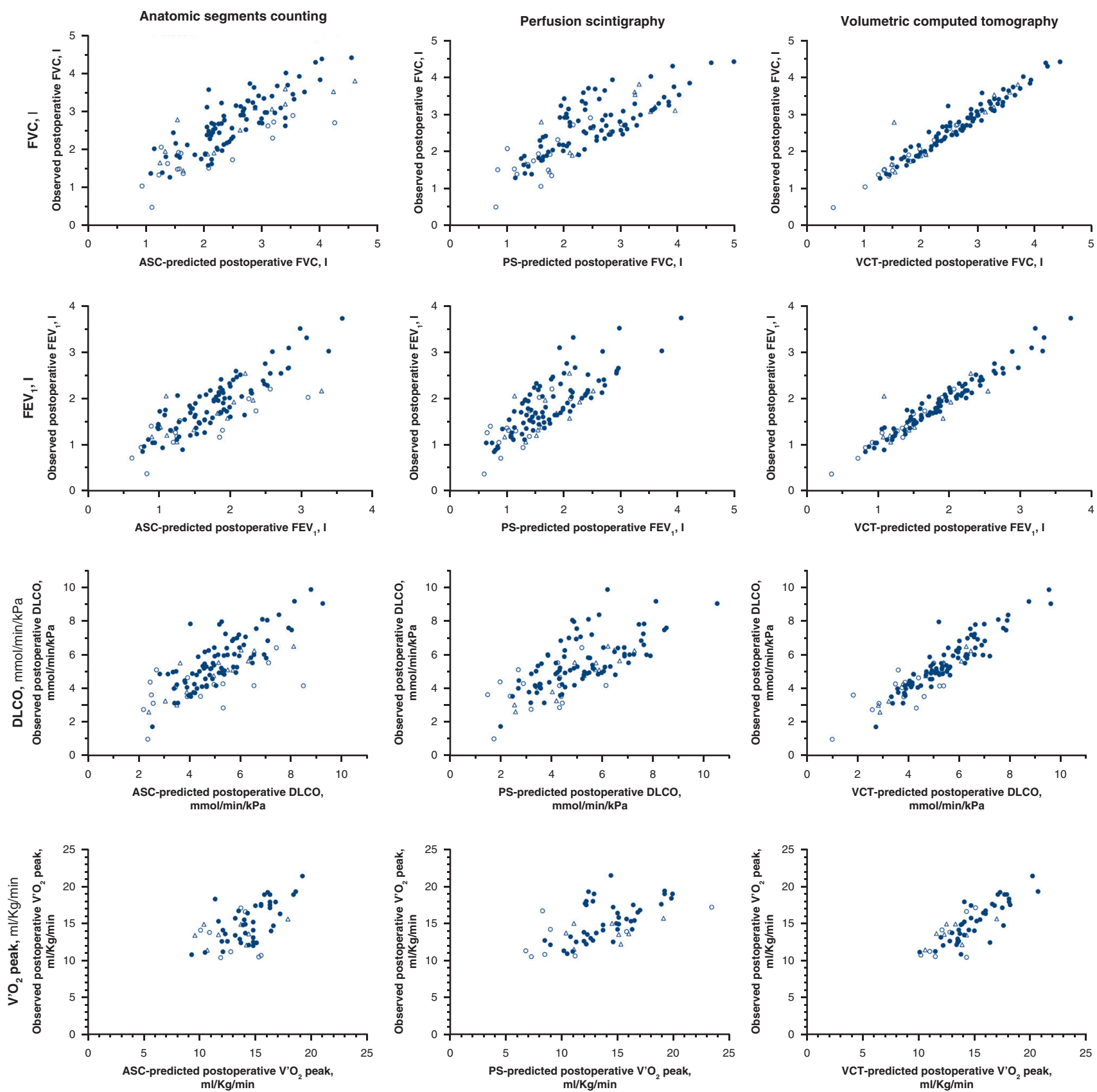

FIGURE 2. Relation between the absolute values of the measured and ppo lung function determined by ASC (left), PS (middle), or volumetric CT (right). Pneumonectomy $(\bigcirc)$, bilobectomy $(\Delta)$, or lobectomy $(\bullet)$. $F V C$, Forced vital capacity; $F E V_{l}$, forced expiratory volume in 1 second; $D L C O$, lung diffusion capacity for carbon monoxide; $V O_{2}$, oxygen uptake; $A S C$, anatomic segments counting; $P S$, perfusion scintigraphy; $V C T$, volumetric computed tomography.

\section{DISCUSSION}

Our results show that volumetric CT provides a better estimation for ppo lung function than conventional methods, such as ASC or pulmonary scintigraphy. With respect to the measured postoperative lung function, predicted values determined by volumetric CT reach a higher correlation, precision, and agreement than the other methods. Moreover, we have developed and validated a set of multivariable regression equations to predict postoperative lung function parameters from volumetric CT, including other anthropometric variables and increasing prediction capacity (Video 1).

The prediction equations generated are applicable to patients considered for lung resection, regardless of the resection planned and the presence or lack of airflow limitation. However, caution should be exercised in patients with severe airflow limitation. In addition, they are specific for each functional parameter, without using a common 

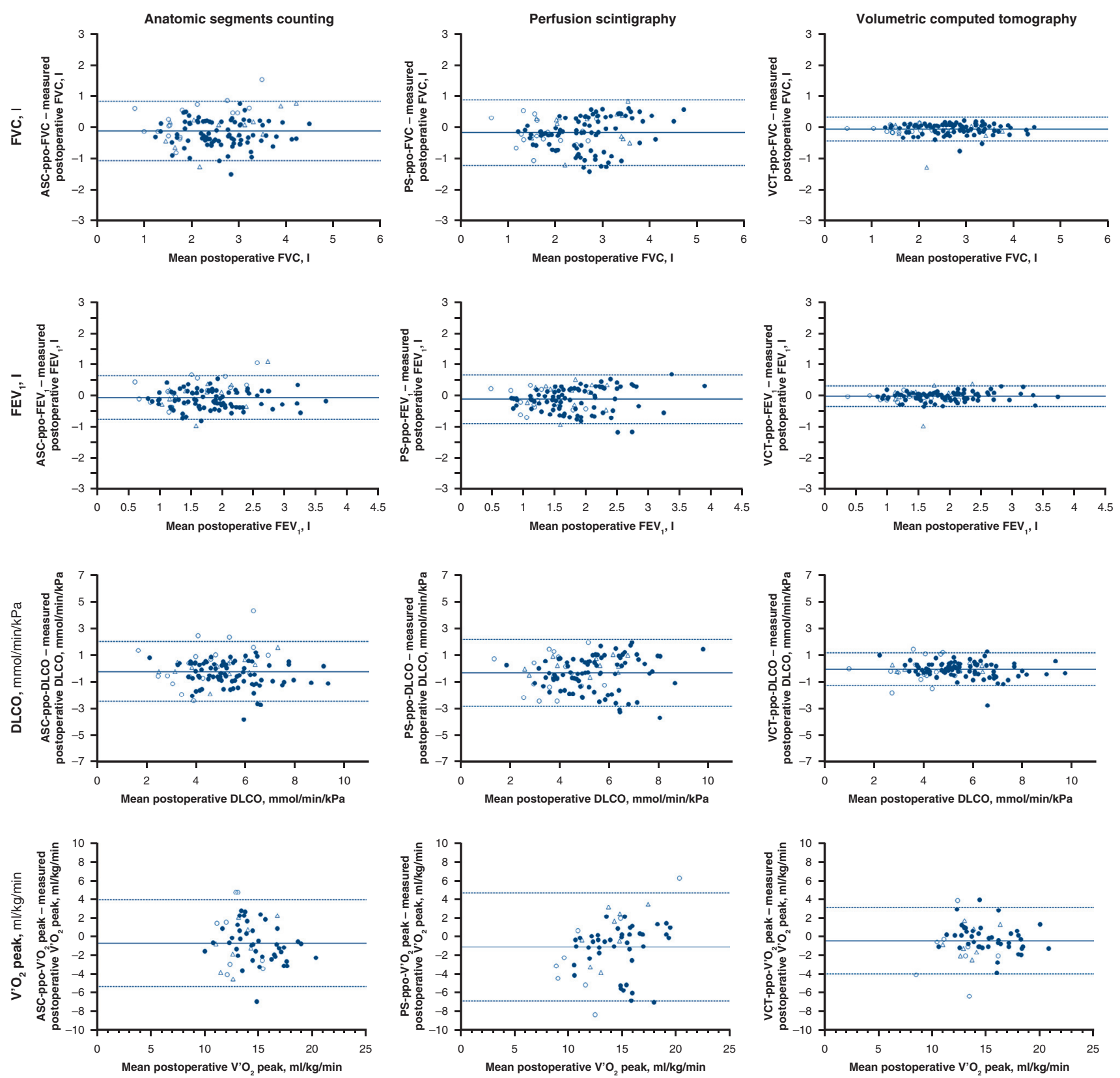

FIGURE 3. Agreement between the absolute values of the measured and ppo lung function determined by ASC (left), PS (middle), or volumetric CT $($ right). The continuous lines represent the mean difference, and the dashed lines represent 2 standard deviations around the mean. Pneumonectomy $(\bigcirc)$, bilobectomy $(\Delta)$, or lobectomy $(\bullet)$ ). $F V C$, Forced vital capacity; $F E V_{1}$, forced expiratory volume in 1 second; $D L C O$, lung diffusion capacity for carbon monoxide; $\mathrm{VO}_{2}$, oxygen uptake.

adjustment percentage for the different functional values. This is particularly important when we consider that lung resection affects the different functional parameters differently. Thus, it has been described that the decreases from preoperative values for $\mathrm{FVC}, \mathrm{FEV}_{1}, \mathrm{DLCO}$, and $\mathrm{VO}_{2}$ peak are $30 \%, 28 \%, 39 \%$, and $28 \%$, respectively, after pneumonectomy, and $13 \%, 8 \%, 20 \%$, and $12 \%$, respectively, after lobectomy. ${ }^{28}$ Similar differences have been reported by other authors. In fact, postoperative decreases in $\mathrm{FEV}_{1}$ of $23 \%$ after pneumonectomy and $8 \%$ after lobectomy have been described, whereas exercise capacity decreased by $16 \%$ after pneumonectomy and $13 \%$ after lobectomy. ${ }^{29}$ Along the same line, Bolliger and colleagues $^{30}$ reported decreases in $\mathrm{FVC}$ of $36 \%$ after pneumonectomy and 6\% after lobectomy, whereas the decreases in $\mathrm{VO}_{2} \max$ were $20 \%$ and $1 \%$, respectively. Furthermore, the equations generated also allow one to incorporate the calculation of the upper and lower limits 
TABLE 3. Parameters related with the postoperative lung function in the univariate and multivariable analyses

\begin{tabular}{|c|c|c|c|c|c|c|c|}
\hline \multirow[b]{3}{*}{ Parameter } & & & & \multicolumn{4}{|c|}{ Multivariable regression analysis } \\
\hline & \multicolumn{3}{|c|}{ Correlation analysis } & \multicolumn{2}{|c|}{$\begin{array}{l}\text { Nonstandardized } \\
\text { coefficients }\end{array}$} & \multirow{2}{*}{$\begin{array}{c}\text { Standardized } \\
\text { coefficients }\end{array}$} & \multirow{2}{*}{$\begin{array}{c}P \\
\text { value }\end{array}$} \\
\hline & $r$ & $95 \% \mathrm{CI}$ & $P$ value & $\mathbf{B}$ & $95 \% \mathrm{CI}$ & & \\
\hline \multicolumn{8}{|l|}{ ppo-FVC, $\%$ predicted } \\
\hline Sex & 0.027 & $-0.158-0.210$ & .779 & -0.031 & - & - & .474 \\
\hline Age, y & 0.067 & $-0.118-0.248$ & .479 & -0.004 & - & - & .911 \\
\hline Height, $\mathrm{cm}$ & -0.181 & $-0.353-0.003$ & .037 & 0.067 & 0.043-0.091 & 0.039 & .027 \\
\hline Weight, kg & 0.009 & $-0.175-0.193$ & .921 & 0.038 & - & - & .349 \\
\hline BMI, $\mathrm{kg} / \mathrm{m}^{2}$ & 0.116 & $-0.069-0.294$ & .218 & 0.036 & - & - & .309 \\
\hline Time since surgery, mo & 0.060 & $-0.125-0.241$ & $<.001$ & 0.012 & - & - & .457 \\
\hline Preoperative FVC, \% predicted & 0.746 & $0.651-0.818$ & .711 & 0.731 & $0.658-0.803$ & 0.702 & $<.001$ \\
\hline CF by ASC & 0.113 & $-0.072-0.291$ & .232 & -0.025 & - & - & .479 \\
\hline CF by PS & 0.288 & $0.110-0.448$ & .002 & -0.045 & - & - & .269 \\
\hline $\mathrm{CF}$ by volumetric $\mathrm{CT}$ & 0.568 & $0.429-0.681$ & $<.001$ & 91.931 & $80.966-102.902$ & 0.567 & $<.001$ \\
\hline \multicolumn{8}{|l|}{ ppo-FEV ${ }_{1}, \%$ predicted } \\
\hline Sex & -0.402 & $-0.546-0.235$ & $<.001$ & -0.018 & - & - & .808 \\
\hline Age, y & -0.459 & $-0.593-0.300$ & $<.001$ & -0.018 & - & - & .807 \\
\hline Height, $\mathrm{cm}$ & 0.444 & $0.283-0.581$ & $<.001$ & -0.081 & - & - & .282 \\
\hline Weight, kg & 0.258 & $0.078-0.422$ & .006 & 0.097 & - & - & .235 \\
\hline BMI, $\mathrm{kg} / \mathrm{m}^{2}$ & 0.053 & $-0.132-0.235$ & .576 & 0.063 & - & - & .340 \\
\hline Time since surgery, mo & 0.157 & $-0.028-0.331$ & .328 & -0.097 & - & - & .188 \\
\hline Preoperative $\mathrm{FEV}_{1}, \%$ predicted & 0.362 & $0.191-0.512$ & $<.001$ & 0.755 & $0.616-0.894$ & 0.764 & $<.001$ \\
\hline CF by ASC & 0.144 & $-0.041-0.319$ & .127 & -0.129 & - & - & .128 \\
\hline CF by PS & 0.121 & $-0.064-0.298$ & .198 & 0.038 & - & - & .634 \\
\hline $\mathrm{CF}$ by volumetric $\mathrm{CT}$ & 0.385 & $0.216-0.531$ & $<.001$ & 80.234 & $53.686-106.782$ & 0.462 & $<.001$ \\
\hline \multicolumn{8}{|l|}{ ppo-DLCO, $\%$ predicted } \\
\hline Sex & -0.014 & $-0.197-0.170$ & .881 & 0.032 & - & - & .521 \\
\hline Age, y & 0.277 & $0.098-0.439$ & .003 & 0.054 & $0.050-0.058$ & 0.018 & .036 \\
\hline Height, $\mathrm{cm}$ & -0.213 & $-0.382-0.030$ & .027 & -0.135 & $-0.181-0.079$ & 0.021 & .012 \\
\hline Weight, kg & 0.184 & $0.000-0.356$ & .045 & 0.045 & $0.021-0.069$ & 0.007 & .044 \\
\hline BMI, $\mathrm{kg} / \mathrm{m}^{2}$ & 0.088 & $-0.097-0.268$ & .353 & 0.050 & - & - & .287 \\
\hline Time since surgery, mo & 0.116 & $-0.069-0.294$ & .469 & -0.044 & - & - & .348 \\
\hline Preoperative DLCO, \% predicted & 0.748 & $0.654-0.819$ & $<.001$ & 0.728 & $0.636-0.820$ & 0.723 & $<.001$ \\
\hline CF by ASC & 0.032 & $-0.153-0.215$ & .739 & 0.024 & - & - & .467 \\
\hline CF by PS & 0.195 & $0.011-0.366$ & .038 & -0.016 & - & - & .521 \\
\hline $\mathrm{CF}$ by volumetric $\mathrm{CT}$ & 0.504 & $0.353-0.630$ & $<.001$ & 75.441 & $60.135-90.747$ & 0.465 & $<.001$ \\
\hline \multicolumn{8}{|l|}{ ppo- $\mathrm{VO}_{2}$ peak, $\mathrm{L} / \mathrm{kg} / \mathrm{min}$} \\
\hline Sex & -0.004 & $-0.262-0.255$ & .976 & 0.084 & - & - & .589 \\
\hline Age, y & 0.075 & $-0.187-0.327$ & .574 & 0.028 & - & - & .861 \\
\hline Height, $\mathrm{cm}$ & 0.012 & $-0.247-0.269$ & .930 & -0.189 & - & - & .202 \\
\hline Weight, kg & -0.103 & $-0.352-0.160$ & .443 & -0.072 & - & - & .664 \\
\hline BMI, $\mathrm{kg} / \mathrm{m}^{2}$ & 0.316 & $0.063-0.531$ & .024 & 0.019 & $0.007-0.031$ & 0.008 & .043 \\
\hline Time since surgery, mo & 0.204 & $-0.057-0.439$ & .318 & 0.196 & - & - & .169 \\
\hline Preoperative $\mathrm{VO}_{2}$ peak, $\mathrm{mL} / \mathrm{kg} / \mathrm{min}$ & 0.673 & $0.502-0.793$ & $<.001$ & 0.769 & $0.461-1.077$ & 0.726 & $<.001$ \\
\hline CF by ASC & 0.038 & $-0.222-0.293$ & .779 & 0.085 & - & - & .486 \\
\hline CF by PS & 0.244 & $-0.015-0.473$ & .065 & -0.090 & - & - & .558 \\
\hline $\mathrm{CF}$ by volumetric $\mathrm{CT}$ & 0.341 & $0.091-0.551$ & .009 & 19.294 & $5.944-32.644$ & 0.388 & .014 \\
\hline
\end{tabular}

$r$, Pearson correlation coefficient; $C I$, confidence interval; $B$, regression coefficient; ppo, predicted postoperative; $F V C$, forced vital capacity; Sex, $0=$ male, $1=$ female; $B M I$, body mass index; $C F$, correction factor; $A S C$, anatomic segments count; $P S$, pulmonary scintigraphy; $C T$, computed tomography; $F E V I$, forced expiratory volume at 1 second; $\mathrm{DLCO}$, lung diffusing capacity for carbon monoxide; $\mathrm{VO}_{2}$, oxygen uptake.

of normal for each prediction, which facilitates interpretation of the margin of variation in the estimation of postoperative lung function.
As for the conventional prediction methods, ASC and PS in our patients have reached an efficacy that is similar to reports in previous studies, with a correlation coefficient 
TABLE 4. Multivariable regression equations to determine postoperative lung function parameters

\begin{tabular}{|c|c|c|c|}
\hline Parameter & Predictive equation & $\mathbf{R}^{2}$ & RSD \\
\hline ppo-FVC, \% predicted & 0.731. FVC + 91.931. (1-FCVRR) - 0.06714. H - 55.776 & 0.980 & 2.4422 \\
\hline ppo-FEV $1, \%$ predicted & 0.755. $\mathrm{FEV}_{1}+80.234 .(1-\mathrm{FCVRR})-60.440$ & 0.982 & 2.3155 \\
\hline ppo-DLCO, \% predicted & 0.728. DLCO + 75.441. (1-FCVRR $)-0.135 . \mathrm{H}-0.05417 . \mathrm{A}+0.04488 . \mathrm{W}-31.699$ & 0.977 & 2.3864 \\
\hline ppo- $\mathrm{VO}_{2}$ peak, $\mathrm{mL} / \mathrm{kg} / \mathrm{min}$ & 0.769. $\mathrm{VO}_{2}$ peak + 19.294. (1-FCVRR $)+0.01925 . \mathrm{BMI}-15.386$ & 0.991 & 0.2572 \\
\hline
\end{tabular}

The lower limit of normal is computed as ppo value $-1.645 \times \mathrm{RSD}$. The upper limit of normal is computed as ppo value $+1.645 \times \mathrm{RSD}$. $R^{2}$, Adjusted coefficient of determination; $R S D$, residual standard deviation; ppo, predicted postoperative; $F V C$, forced vital capacity; $F C V R R$, functional contribution of ventilation of the region to be resected measured by volumetric computed tomography; $H$, height in $\mathrm{cm} ; F E V_{l}$, forced expiratory volume in 1 second; $D L C O$, lung diffusing capacity of carbon monoxide; $A$, age in years; $W$, weight in $\mathrm{kg}$; $V O_{2}$, oxygen uptake; $B M I$, body mass index in $\mathrm{kg} / \mathrm{m}^{2}$.

ranging from 0.70 to 0.87 for most parameters ${ }^{5,31,32}$ and limits of agreement similar to those obtained in our study. ${ }^{16}$ However, as previously mentioned, the PS, which estimates the functional contribution of a lobe or an entire lung by drawing regions-of-interest on planar perfusion images acquired with a gamma camera after injection of technetium- $99 \mathrm{~m}$-labeled macroaggregate of albumin, ${ }^{33}$ is not available in all centers, probably because of the costs of the equipment and the procedure. In addition, this technique generates an additional dose of radiation and causes more delay in the patient evaluation.
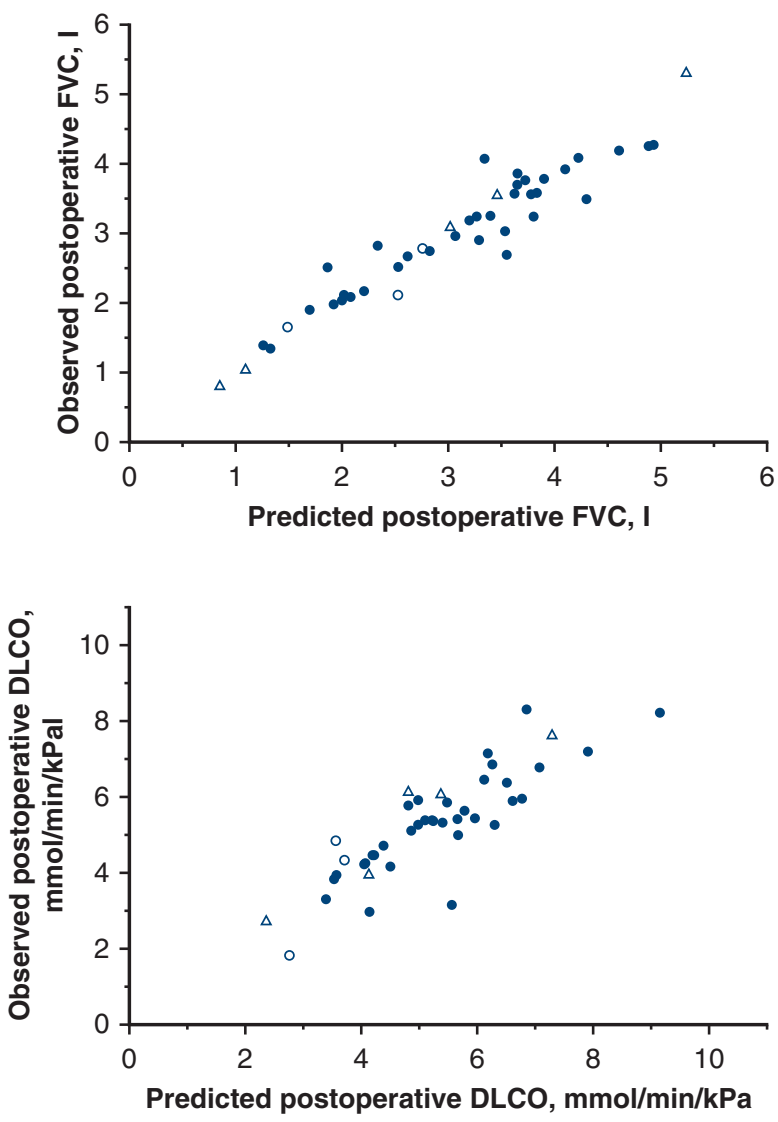

In contrast, $\mathrm{CT}$ is an interesting alternative. The first predictions of approximate postoperative lung function from CT were done with densitometry analysis. Lung volume was estimated by multiplying the area of each functionally relevant lung tissue by the slice thickness, and ppo lung function was calculated by subtracting the volume of the area to be resected from the total functional lung volume. ${ }^{13}$ In a small group of patients, it was reported that spirometric values predicted with this approximation correlated well with postoperative $\mathrm{FEV}_{1}$ and $\mathrm{FVC}$ measurements. ${ }^{13}$ In comparison with PS, both methods
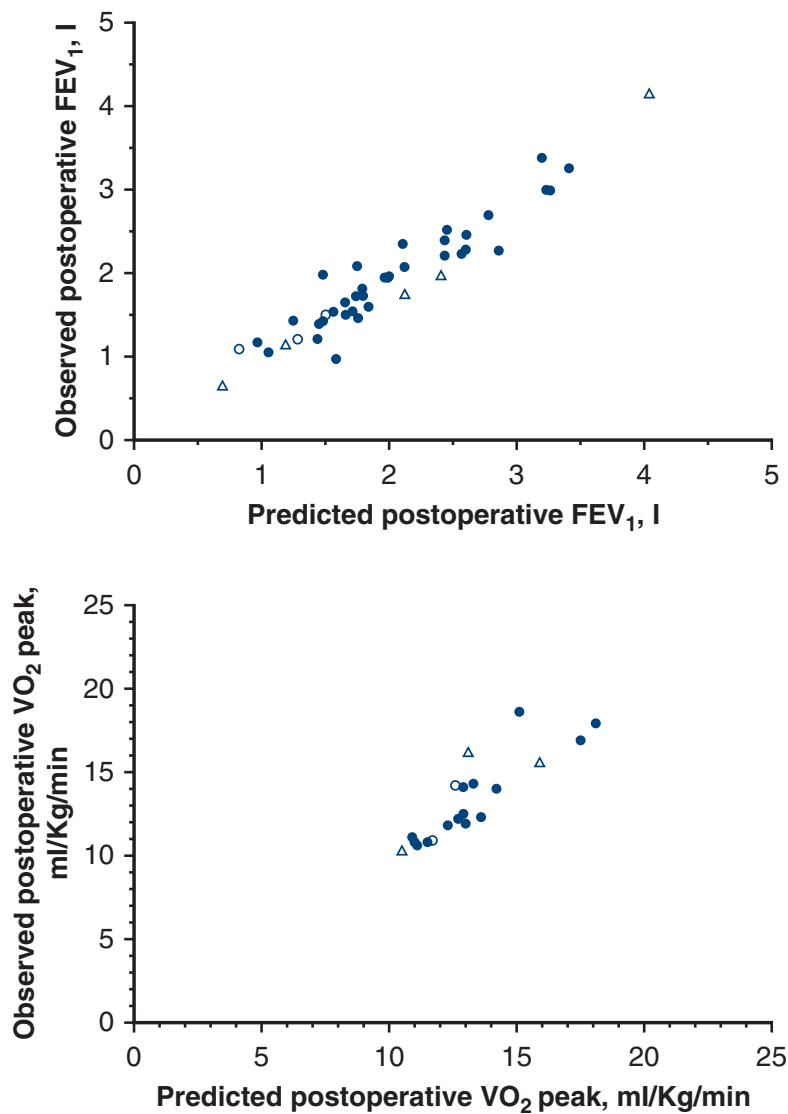

FIGURE 4. Relation between the absolute values of the measured and ppo lung function using the multivariable regression equations in the validation cohort. Pneumonectomy $(\bigcirc)$, bilobectomy $(\Delta)$, or lobectomy $(\bullet)$. FVC, Forced vital capacity; $F E V_{1}$, forced expiratory volume in 1 second; $D L C O$, lung diffusion capacity for carbon monoxide; $V_{2}$, oxygen uptake. 

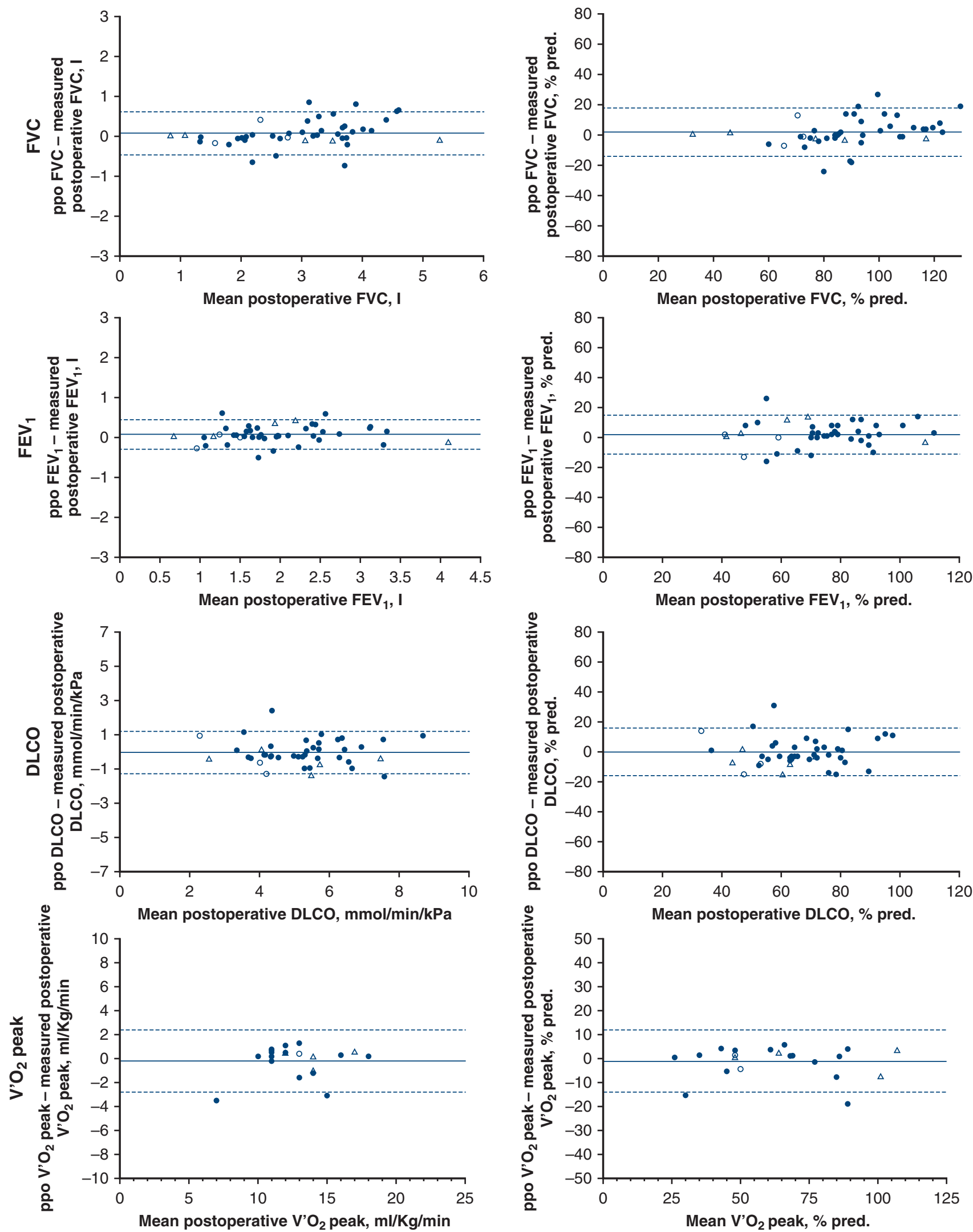

FIGURE 5. Agreement between the measured and ppo lung function using the multivariate regression equations in the validation cohort, expressed as absolute value (left) or percentage of predicted (right). The continuous lines represent the mean difference, and the dashed lines represent 2 standard deviations around the mean. Pneumonectomy $(\bigcirc)$, bilobectomy $(\Delta)$, or lobectomy $(\mathbf{O})$. $F V C$, forced vital capacity; $F E V_{1}$, forced expiratory volume in 1 second; $D L C O$, lung diffusion capacity for carbon monoxide; $V O_{2}$, oxygen uptake. 


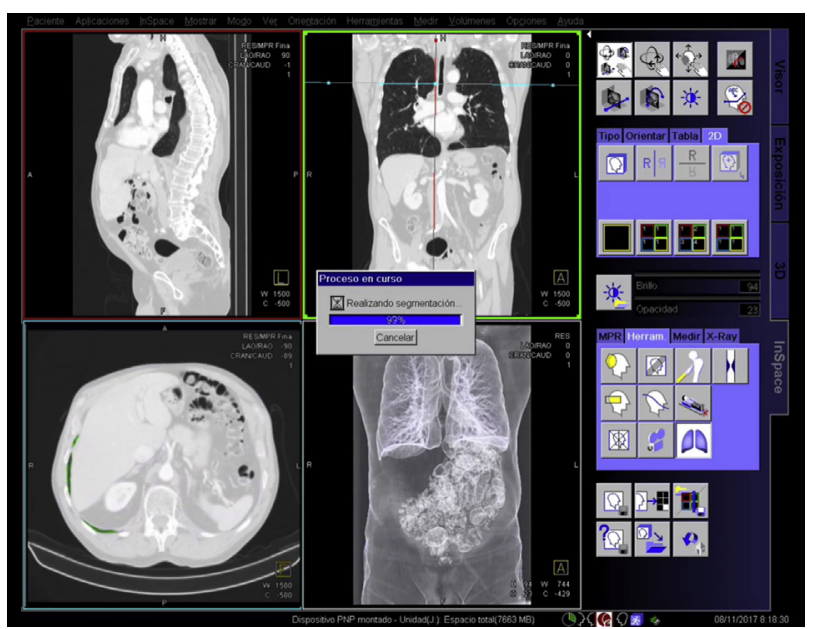

VIDEO 1. Relevance of volumetric CT analysis to operability study of patients with lung cancer. Video available at: https://www.jtcvs.org/ article/S0022-5223(18)32018-X/fulltext.

reach a good correlation with measured postoperative $\mathrm{FEV}_{1}$ in patients who underwent pneumonectomy or lobectomy. ${ }^{12,14,15}$ However, in patients with normal or only mildly decreased lung function, perfusion lung scanning was slightly superior to quantitative CT, mainly in the prediction of FVC, DLCO, and $\mathrm{VO}_{2}$ peak. ${ }^{16}$ Moreover, the available information on the accuracy of the estimation of postoperative function by $\mathrm{CT}$ in patients with airflow limitation is limited. ${ }^{17}$

The information available about the accuracy of the 3-dimensional CT for predicting postoperative lung function is still scarce and, to our knowledge, limited to the description of a good correlation between ppo-FEV $\mathrm{F}_{1}$ and measured postoperative $\mathrm{FEV}_{1}$ in a small group of patients. ${ }^{19}$ However, our results show that volumetric CT has a greater capacity for predicting postoperative lung function than the classic methods and far surpasses the degree of precision obtained with the estimation of lung volumes based on classic densitometry CT. ${ }^{12-17}$ These results, together with the relative accessibility of this type of analysis (software available for almost all CT equipment at an additional cost of $\sim \$ 17,000$ ), make it an ideal procedure for the evaluation of operability. Likewise, the accuracy in the prediction of postoperative functional values by means of volumetric CT is also greater than that reported for alternative low-cost procedures, such as quantitative breath sound measurement using vibration response imaging. ${ }^{11,34}$

In recent years, it has also been proposed to predict postoperative lung function using single-photon emission $\mathrm{CT},{ }^{10}$ 4-dimensional CT ventilation,, 35 positron emission tomography/CT, ${ }^{36}$ or dynamic contrast-enhanced perfusion magnetic resonance imaging. ${ }^{12,37}$ The correlation coefficients between measured postoperative $\mathrm{FEV}_{1}$ and that determined by these procedures range from
0.81 to $0.99,9,10,12,38,39$ which do not surpass those obtained by volumetric CT, despite requiring more expensive and less-accessible procedures that, in some cases, involve additional radiation for the patient. In comparison, the evaluation of operability by means of volumetric $\mathrm{CT}$ uses an examination that is required in all patients with suspected lung cancer, without causing discomfort or additional risk for the patient. At the same time, its cost is low and limited to the acquisition of semiautomatic analysis software, and the estimated image postprocessing time is 10 to 15 minutes.

\section{Study Limitations}

Our study has several limitations. First, it is a single-center study analyzing a sample of patients operated on by a single surgical team. A $P$ value of .05 was used to establish significance without adjustment for multiplicity, and the sample size was small for predictive modeling. Second, we did not analyze the impact on lung function of the surgical approach used, because patients who had been treated by thoracotomy or by video-assisted thoracoscopic surgery were analyzed together. Third, arbitrarily and in accordance with most of the previous literature, it was decided to evaluate the postoperative lung function 3 to 4 months after lung resection surgery. However, this period might not be sufficient in all cases to determine the definitive postoperative function. In fact, although the loss of lung function caused by pneumonectomy seems to remain stable over time, it has been described that some patients who undergo lobectomy experience a mild recovery of $\mathrm{FEV}_{1}$ and peak $\mathrm{VO}_{2}$ between 3 and 6 months after surgery. ${ }^{12}$ Fourth, similarly to scintigraphy, the segmentation of the lung on the CT divides the lung into thirds, rather than actual anatomic segments. Fifth, only 6 of the 45 patients with airflow limitation in our study had severe obstruction. Therefore, precaution must be taken when applying the equations generated in patients with very severe chronic obstructive pulmonary disease, especially those with emphysema. This is particularly important for the so-called lobar volume reduction effect, which suggests that in patients with lung cancer and severe chronic obstructive pulmonary disease, the resection of the most affected parenchyma may determine an improvement in respiratory mechanics and elastic recoil, even originating an improvement in respiratory function 3 to 6 months after lobectomy. ${ }^{31,38,39}$

\section{CONCLUSIONS}

Our study shows that volumetric $\mathrm{CT}$ is an accurate and precise method for predicting postoperative lung function in patients undergoing lung resection, achieving better performance than conventionally used procedures, such as ASC or PS. Therefore, and given that CT is done systematically in the staging of all patients with suspected 
lung cancer, the volumetric analysis could simultaneously provide the information necessary for the evaluation of operability. To generalize this procedure, more studies are needed to evaluate its accuracy in other centers, with several surgical procedures and on large patient samples including more ethnic groups and a broad spectrum of comorbidities.

\section{Conflict of Interest Statement}

Authors have nothing to disclose with regard to commercial support.

\section{References}

1. Howington JA, Blum MG, Chang AC, Balekian AA, Murthy SC. Treatment of stage I and II non-small cell lung cancer: diagnosis and management of lung cancer, 3rd ed: American College of Chest Physicians evidence-based clinical practice guidelines. Chest. 2013;143:e278S-313S.

2. Brunelli A, Kim AW, Berger KI, Addrizzo-Harris DJ. Physiologic evaluation of the patient with lung cancer being considered for resectional surgery: diagnosis and management of lung cancer, 3rd ed: American College of Chest Physicians evidence-based clinical practice guidelines. Chest. 2013;143:e166S-90S.

3. Brunelli A, Charloux A, Bolliger CT, Rocco G, Sculier JP, Varela G, et al. European Respiratory Society and European Society of Thoracic Surgeons Joint Task Force on Fitness for Radical Therapy. ERS/ESTS clinical guidelines on fitness for radical therapy in lung cancer patients (surgery and chemo-radiotherapy). Eur Respir J. 2009;34:17-41.

4. Ferguson MK, Watson S, Johnson E, Vigneswaran WT. Predicted postoperative lung function is associated with all-cause long-term mortality after major lung resection for cancer. Eur J Cardiothorac Surg. 2014;45:660-4.

5. Pierce RJ, Copland JM, Sharpe K, Barter CE. Preoperative risk evaluation for lung cancer resection: predicted postoperative product as a predictor of surgical mortality. Am J Respir Crit Care Med. 1994;150:947-55.

6. Corris PA, Ellis DA, Hawkins T, Gibson GJ. Use of radionuclide scanning in the preoperative estimation of pulmonary function after pneumonectomy. Thorax. 1987:42:285-91.

7. Win T, Tasker AD, Groves AM, White C, Ritchie AJ, Wells FC, et al. Ventilation-perfusion scintigraphy to predict postoperative pulmonary function in lung cancer patients undergoing pneumonectomy. AJR Am J Roentgenol. 2006; 187:1260-5

8. Petersson J, Sanchez-Crespo A, Rohdin M, Montmerle S, Nyrén S, Jacobsson H, et al. Physiological evaluation of a new quantitative SPECT method measuring regional ventilation and perfusion. J Appl Physiol. 2004;96:1127-36.

9. Eslick EM, Bailey DL, Harris B, Kipritidis J, Stevens M, Li BT, et al. Measurement of preoperative lobar lung function with computed tomography ventilation imaging: progress towards rapid stratification of lung cancer lobectomy patients with abnormal lung function. Eur J Cardiothorac Surg. 2016;49:1075-82

10. Piai DB, Quagliatto R Jr, Toro I, Cunha Neto C, Etchbehere E, Camargo E. The use of SPECT in preoperative assessment of patients with lung cancer. Eur Respir J. $2004 ; 24: 258-62$.

11. Marina N, Rodríguez-Trigo G, Jiménez U, Morales B, López de Santa María E, Pijoan JI, et al. Vibration response imaging versus perfusion scan in lung cancer surgery evaluation. J Thorac Cardiovasc Surg. 2014;147:816-21.

12. Ohno Y, Koyama H, Nogami M, Takenaka D, Matsumoto S, Yoshimura M, et al. Postoperative lung function in lung cancer patients: comparative analysis of predictive capability of MRI, CT, and SPECT. AJR Am J Roentgenol. 2007; 189:400-8.

13. Wu MT, Chang JM, Chiang A, Lu JY, Hsu HK, Hsu WH, et al. Use of quantitative $\mathrm{CT}$ to predict postoperative lung function in patients with lung cancer. Radiology. 1994;191:257-62.

14. Olsen GN, Block AJ, Tobias JA. Prediction of postpneumonectomy pulmonary function using quantitative macroaggregate lung scanning. Chest. 1974;66:13-6.

15. Wu MT, Pan HB, Chiang AA, Hsu HK, Chang HC, Peng NJ, et al. Prediction of postoperative lung function in patients with lung cancer: comparison of quantitative CT with perfusion scintigraphy. AJR Am J Roentgenol. 2002;178: 667-72.

16. Bolliger CT, Gückel C, Engel H, Stöhr S, Wyser CP, Schoetzau A, et al. Prediction of functional reserves after lung resection: comparison between quantitative computed tomography, scintigraphy, and anatomy. Respiration 2002;69:482-9.

17. Sverzellati N, Chetta A, Calabrò E, Carbognani P, Internullo E, Olivieri D, et al. Reliability of quantitative computed tomography to predict postoperative lung function in patients with chronic obstructive pulmonary disease having a lobectomy. J Comput Assist Tomogr. 2005;29:819-24.

18. Park CH, Kim TH, Lee S, Paik HC, Haam SJ. New predictive equation for lung volume using chest computed tomography for size matching in lung transplantation. Transplant Proc. 2015;47:498-503.

19. Ueda K, Tanaka T, Li TS, Tanaka N, Hamano K. Quantitative computed tomography for the prediction of pulmonary function after cancer surgery: a simple method using simulation software. Eur J Cardiothorac Surg. 2009; $35: 414-8$.

20. Wyser C, Stulz P, Solèr M, Tamm M, Müller-Brand J, Habicht J, et al. Prospective evaluation of an algorithm for the functional assessment of lung resection candidates. Am J Respir Crit Care Med. 1999;159:1450-6.

21. Puente-Maestu L, Villar F, González-Casurrán G, Moreno N, Martínez Y, Simón C, et al. Early and long-term validation of an algorithm assessing fitness for surgery in patients with postoperative FEV1 and diffusing capacity of the lung for carbon monoxide $<40 \%$. Chest. 2011;139:1430-8.

22. Groome PA, Bolejack V, Crowley JJ, Kennedy C, Krasnik M, Sobin LH, et al The IASLC Lung Cancer Staging Project: validation of the proposals for revision of the $\mathrm{T}, \mathrm{N}$, and $\mathrm{M}$ descriptors and consequent stage groupings in the forthcoming (seventh) edition of the TNM classification of malignant tumours. J Thorac Oncol. 2007;2:694-705.

23. Quanjer PH, Trammeling GJ, Cotes JE, Pedersen OF, Peslin R, Yernault JC. Lung volumes and forced ventilatory flows. Report Working Party Standardization of Lung Function Tests. European Community for Steel and Coal. Official Statement of the European Respiratory Society. Eur Respir J. 1993;6(Suppl 16): $5 \mathrm{~s}-40 \mathrm{~s}$.

24. Cotes JE, Chinn DJ, Quanjer PhH, Roca J, Yernault JC. Standardization of the measurement of transfer factor (diffusing capacity). Report Working Party Standardization of Lung Function Tests, European Community for Steel and Coal. Official Statement of the European Respiratory Society. Eur Respir J. 1993;6(Suppl 16):41s-52s.

25. Jones NL, Makrides L, Hitchcock C, Chypchar T, McCartney N. Normal standards for an incremental progressive cycle ergometer test. Am Rev Respir Dis. 1985;131:700-8.

26. Nakahara K, Monden Y, Ohno K, Miyoshi S, Maeda H, Kawashima Y. A method for predicting postoperative lung function and its relation to postoperative complications in patients with lung cancer. Ann Thorac Surg. 1985;39:260-5.

27. Bland JM, Altman DG. Statistical methods for assessing agreement between two methods of clinical measurement. Lancet. 1986;1:307-10.

28. Wang JS, Abboud RT, Wang LM. Effect of lung resection on exercise capacity and on carbon monoxide diffusing capacity during exercise. Chest. 2006;129: 863-72.

29. Larsen KR, Svendsen UG, Milman N, Brenøe J, Petersen BN. Cardiopulmonary function at rest and during exercise after resection for bronchogenic carcinoma. Ann Thorac Surg. 1997;64:960-4.

30. Bolliger CT, Jordan P, Soler M, Stulz P, Tamm M, Wyser C, et al. Pulmonary function and exercise capacity after lung resection. Eur Respir J. 1996;9:415-21.

31. Brunelli A, Refai M, Salati M, Xiumé F, Sabbatini A. Predicted versus observed FEV1 and DLCO after major lung resection: a prospective evaluation at different postoperative periods. Ann Thorac Surg. 2007;83:1134-9.

32. Bolliger CT, Wyser C, Roser H, Solèr M, Perruchoud AP. Lung scanning and exercise testing for the prediction of postoperative performance in lung resection candidates at increased risk for complications. Chest. 1995;108:341-8.

33. Toney LK, Wanner M, Miyaoka RS, Alessio AM, Wood DE, Vesselle H. Improved prediction of lobar perfusion contribution using technetium$99 \mathrm{~m}$-labeled macroaggregate of albumin single photon emission computed tomography/computed tomography with attenuation correction. J Thorac Cardiovasc Surg. 2014;148:2345-52.

34. Westhoff M, Herth F, Albert M, Dienemann H, Eberhardt R. A new method to predict values for postoperative lung function and surgical risk of lung resection by quantitative breath sound measurements. Am J Clin Oncol. 2013;36:273-8.

35. Vinogradskiy Y, Jackson M, Schubert L, Jones B, Castillo R, Castillo E, et al Assessing the use of 4DCT-ventilation in pre-operative surgical lung cancer evaluation. Med Phys. 2017;44:200-8.

36. Le Roux PY, Leong TL, Barnett SA, Hicks RJ, Callahan J, Eu P, et al. Gallium-68 perfusion positron emission tomography/computed tomography to assess 
pulmonary function in lung cancer patients undergoing surgery. Cancer Imaging. 2016;16:24.

37. Ohno Y, Koyama H, Nogami M, Takenaka D, Onishi Y, Matsumoto K, et al. State-of-the-art radiological techniques improve the assessment of postoperative lung function in patients with non-small cell lung cancer. Eur J Radiol. 2011;77: 97-104.

38. Linden PA, Bueno R, Colson YL, Jaklitsch MT, Lukanich J, Mentzer S, et al. Lung resection in patients with preoperative FEV1 $<35 \%$ predicted. Chest. 2005;127:1984-90
39. Brunelli A, Xiumé F, Refai M, Salati M, Marasco R, Sciarra V, et al. Evaluation of expiratory volume, diffusion capacity, and exercise tolerance following major lung resection: a prospective follow-up analysis. Chest. 2007; 131:141-7.

Key Words: computed tomography, lung cancer, lung function, operability, surgery 


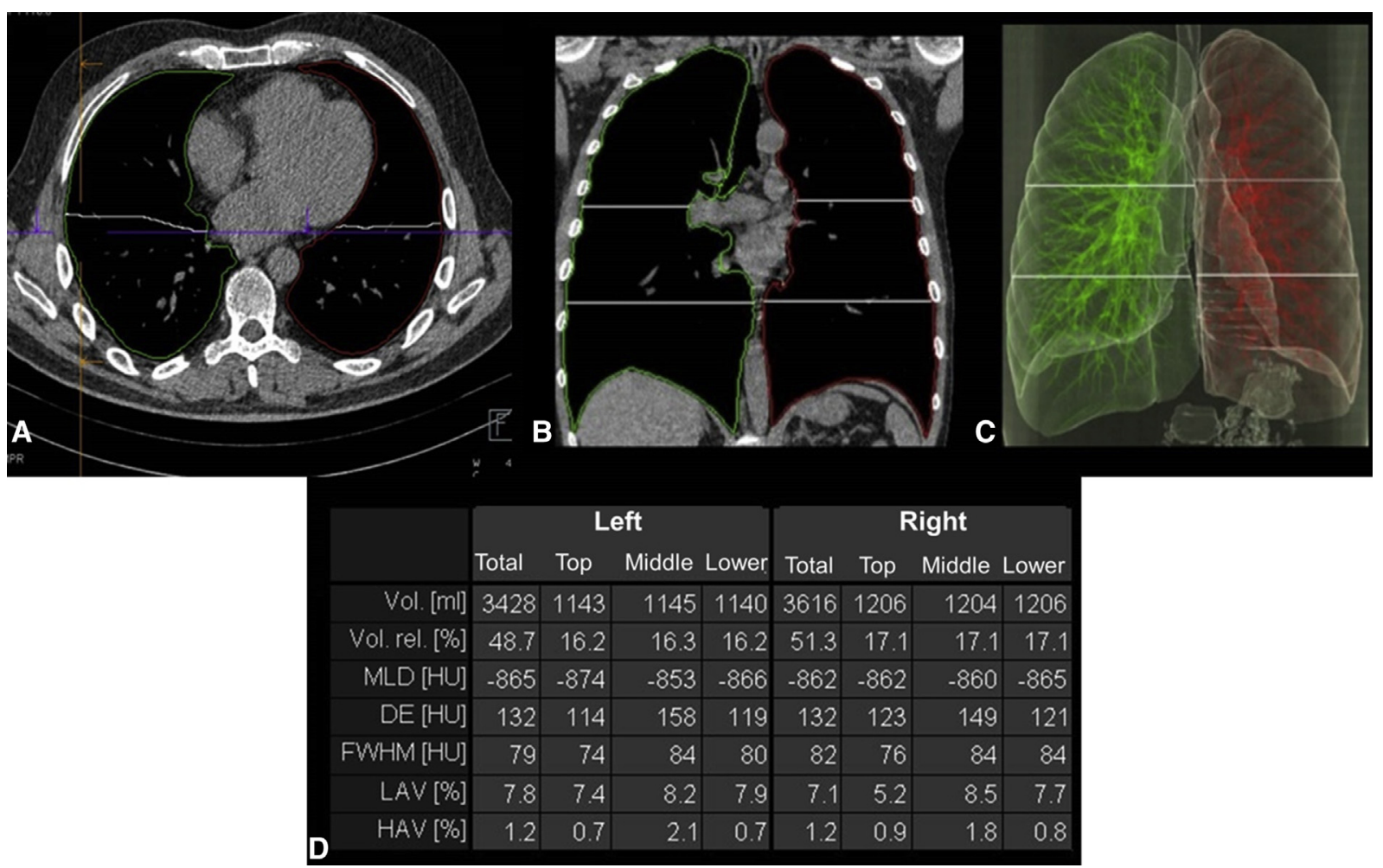

FIGURE E1. An example patient showing the segmentation of the thorax in the axial (A) and coronal (B) views to obtain a volumetric representation of both lungs with the division of lung areas (C). The software provides values for absolute and relative lung volumes (Vol. and Vol.rel., respectively), as well as mean lung density $(M L D)$, standard deviation $(D E)$, full width at half maximum (FWHM), low attenuation volume ( $L A V)$, and high attenuation volume (HAV) (D). 

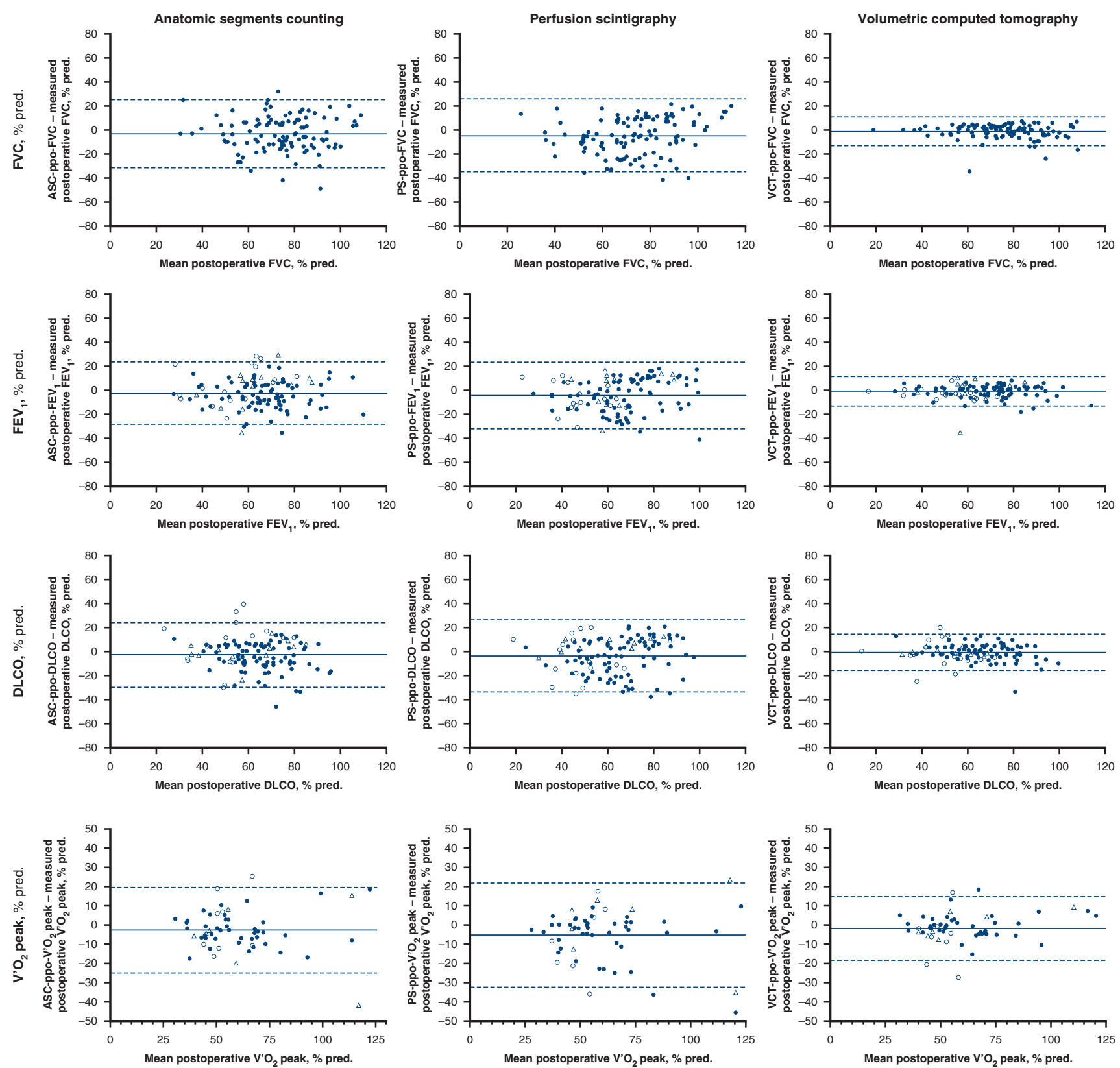

FIGURE E2. Agreement between the percentage of predicted of the measured and ppo lung function determined by anatomic segments counting (left), PS (middle), or volumetric CT (right). The continuous lines represent the mean difference, and the dashed lines represent 2 standard deviations around the mean. Pneumonectomy $(\bigcirc)$, bilobectomy $(\Delta)$, or lobectomy $(\bullet)$ ). $F V C$, Forced vital capacity; $F E V_{l}$, forced expiratory volume in 1 second; $\mathrm{DLCO}$, lung diffusing capacity of carbon monoxide; $\mathrm{VO}_{2}$, oxygen uptake. 
TABLE E1. Relation and reliability of the 3 evaluated methods to predict postoperative lung function with respect to the measured postoperative lung function

\begin{tabular}{|c|c|c|c|c|c|c|}
\hline \multirow[b]{2}{*}{ Parameter } & \multicolumn{3}{|c|}{$\begin{array}{l}\text { Pearson correlation } \\
\text { coefficient }(95 \% \text { CI })\end{array}$} & \multicolumn{3}{|c|}{$\begin{array}{l}\text { Intraclass correlation } \\
\text { coefficient }(95 \% \mathbf{C I})\end{array}$} \\
\hline & $\begin{array}{c}\text { Anatomic } \\
\text { segments counting }\end{array}$ & PS & Volumetric CT & $\begin{array}{c}\text { Anatomic } \\
\text { segments counting }\end{array}$ & PS & Volumetric CT \\
\hline FVC, 1 & $0.820(0.749-0.872)$ & $0.801(0.724-0.858)$ & $0.969(0.948-0.982)$ & $0.814(0.739-0.869)$ & $0.783(0.689-0.849)$ & $0.969(0.955-0.978)$ \\
\hline $\begin{array}{l}\text { FVC, } \\
\quad \% \text { predicted }\end{array}$ & $0.673(0.558-0.763)$ & $0.706(0.600-0.788)$ & $0.941(0.902-0.965)$ & $0.663(0.543-0.756)$ & $0.678(0.553-0.771)$ & $0.939(0.912-0.958)$ \\
\hline $\mathrm{FEV}_{1}, 1$ & $0.873(0.821-0.911)$ & $0.806(0.730-0.862)$ & $0.964(0.940-0.979)$ & $0.835(0.770-0.883)$ & $0.795(0.711-0.856)$ & $0.964(0.948-0.975)$ \\
\hline $\begin{array}{l}\mathrm{FEV}_{1}, \\
\quad \% \text { predicted }\end{array}$ & $0.718(0.615-0.797)$ & $0.713(0.609-0.793)$ & $0.936(0.894-0.962)$ & $0.715(0.612-0.794)$ & $0.695(0.571-0.782)$ & $0.936(0.909-0.956)$ \\
\hline $\begin{array}{l}\mathrm{DLCO}, \\
\qquad \mathrm{mmol} / \mathrm{min} / \mathrm{kPa}\end{array}$ & $0.734(0.636-0.809)$ & $0.700(0.592-0.783)$ & $0.921(0.870-0.953)$ & $0.729(0.630-0.805)$ & $0.690(0.578-0.776)$ & $0.920(0.886-0.944)$ \\
\hline $\begin{array}{l}\text { DLCO, } \\
\% \text { predicted }\end{array}$ & $0.659(0.541-0.752)$ & $0.650(0.529-0.745)$ & $0.897(0.831-0.938)$ & $0.649(0.529-0.744)$ & $0.637(0.511-0.736)$ & $0.894(0.850-0.926)$ \\
\hline $\begin{array}{l}\mathrm{VO}_{2} \text { peak } \\
\mathrm{mL} / \mathrm{kg} / \mathrm{min}\end{array}$ & $0.573(0.435-0.685)$ & $0.578(0.441-0.689)$ & $0.779(0.652-0.864)$ & $0.552(0.346-0.708)$ & $0.532(0.311-0.697)$ & $0.776(0.649-0.861)$ \\
\hline $\begin{array}{l}\mathrm{VO}_{2} \text { peak, } \\
\% \text { predicted }\end{array}$ & $0.887(0.840-0.921)$ & $0.834(0.768-0.883)$ & $0.940(0.900-0.964)$ & $0.882(0.808-0.929)$ & $0.815(0.686-0.891)$ & $0.939(0.899-0.963)$ \\
\hline
\end{tabular}


TABLE E2. Limits of agreement between the measured and the predicted postoperative lung function according to the type of resection performed

\begin{tabular}{|c|c|c|c|}
\hline Parameter & Pneumonectomy or bilobectomy $(n=30)$ & Lobectomy $(n=84)$ & Overall $(n=114)$ \\
\hline \multicolumn{4}{|l|}{$\mathrm{FVC}, 1$} \\
\hline Anatomic segments counting & -0.98 to 1.28 & -1.01 to 0.62 & -1.05 to 0.85 \\
\hline PS & -1.04 to 0.87 & -1.26 to 0.90 & -1.21 to 0.90 \\
\hline Volumetric CT & -0.56 to 0.43 & -0.36 to 0.31 & -0.42 to 0.35 \\
\hline \multicolumn{4}{|l|}{ FVC, $\%$ predicted } \\
\hline Anatomic segments counting & -28 to 36 & -31 to 20 & -32 to 25 \\
\hline PS & -32 to 27 & -36 to 25 & -35 to 26 \\
\hline Volumetric CT & -16 to 13 & -12 to 10 & -13 to 11 \\
\hline \multicolumn{4}{|l|}{$\mathrm{FEV}_{1}, 1$} \\
\hline Anatomic segments counting & -0.77 to 1.01 & -0.69 to 0.47 & -0.75 to 0.65 \\
\hline PS & -0.79 to 0.67 & -0.91 to 0.68 & -0.88 to 0.68 \\
\hline Volumetric CT & -0.49 to 0.42 & -0.27 to 0.27 & -0.34 to 0.32 \\
\hline \multicolumn{4}{|l|}{$\mathrm{FEV}_{1}, \%$ predicted } \\
\hline Anatomic segments counting & -27 to 35 & -27 to 18 & -28 to 24 \\
\hline PS & -30 to 25 & -32 to 23 & -32 to 24 \\
\hline Volumetric CT & -18 to 15 & -11 to 10 & -13 to 12 \\
\hline \multicolumn{4}{|l|}{$\mathrm{DLCO}, \mathrm{mmol} / \mathrm{min} / \mathrm{kPa}$} \\
\hline Anatomic segments counting & -2.41 to 3.10 & -2.24 to 1.48 & -2.41 to 2.02 \\
\hline PS & -2.35 to 2.21 & -2.92 to 2.23 & -2.77 to 2.23 \\
\hline Volumetric CT & -1.41 to 1.37 & -1.19 to 1.12 & -1.25 to 1.18 \\
\hline \multicolumn{4}{|l|}{ DLCO, $\%$ predicted } \\
\hline Anatomic segments counting & -29 to 35 & -28 to 19 & -29 to 24 \\
\hline PS & -30 to 28 & -34 to 26 & -33 to 26 \\
\hline Volumetric CT & -18 to 17 & -15 to 14 & -15 to 15 \\
\hline \multicolumn{4}{|l|}{$\mathrm{VO}_{2}$ peak, $\mathrm{mL} / \mathrm{kg} / \mathrm{min}$} \\
\hline Anatomic segments counting & -6.55 to 5.69 & -4.74 to 3.29 & -5.29 to 4.00 \\
\hline PS & -8.38 to 7.01 & -6.18 to 3.76 & -6.86 to 4.73 \\
\hline Volumetric CT & -5.75 to 3.75 & -2.97 to 2.78 & -3.89 to 3.20 \\
\hline \multicolumn{4}{|l|}{$\mathrm{VO}_{2}$ peak, $\%$ predicted } \\
\hline Anatomic segments counting & -35 to 31 & -20 to 15 & -25 to 20 \\
\hline PS & -40 to 32 & -29 to 18 & -32 to 22 \\
\hline Volumetric $\mathrm{CT}$ & -28 to 19 & -13 to 12 & -18 to 15 \\
\hline
\end{tabular}

$F V C$, Forced vital capacity; $P S$, pulmonary scintigraphy; $C T$, computed tomography; $F E V_{1}$, forced expiratory volume in 1 second; $D L C O$, lung diffusing capacity of carbon monoxide; $\mathrm{VO}_{2}$, oxygen uptake. 
TABLE E3. Limits of agreement between the measured and the predicted postoperative lung function according to the presence or absence of airflow limitation

\begin{tabular}{|c|c|c|}
\hline Parameter & Normal spirometry $(n=69)$ & Airflow limitation $(n=45)$ \\
\hline \multicolumn{3}{|l|}{ FVC, 1} \\
\hline Anatomic segments counting & -1.02 to 0.92 & -1.10 to 0.72 \\
\hline PS & -1.18 to 0.90 & -1.26 to 0.89 \\
\hline Volumetric CT & -0.42 to 0.37 & -0.42 to 0.32 \\
\hline \multicolumn{3}{|l|}{ FVC, $\%$ predicted } \\
\hline Anatomic segments counting & -31 to 28 & -32 to 20 \\
\hline PS & -32 to 25 & -39 to 27 \\
\hline Volumetric CT & -13 to 11 & -14 to 10 \\
\hline \multicolumn{3}{|l|}{$\mathrm{FEV}_{1}, 1$} \\
\hline Anatomic segments counting & -0.79 to 0.76 & -0.65 to 0.45 \\
\hline PS & -0.93 to 0.77 & -0.78 to 0.53 \\
\hline Volumetric CT & -0.37 to 0.39 & -0.25 to 0.18 \\
\hline \multicolumn{3}{|l|}{$\mathrm{FEV}_{1}, \%$ predicted } \\
\hline Anatomic segments counting & -30 to 28 & -24 to 16 \\
\hline PS & -32 to 26 & -31 to 20 \\
\hline Volumetric CT & -14 to 14 & -10 to 7 \\
\hline \multicolumn{3}{|l|}{$\mathrm{DLCO}, \mathrm{mmol} / \mathrm{min} / \mathrm{kPa}$} \\
\hline Anatomic segments counting & -2.61 to 2.31 & -2.04 to 1.53 \\
\hline PS & -2.96 to 2.38 & -2.50 to 2.00 \\
\hline Volumetric CT & -1.38 to 1.26 & -1.02 to 1.05 \\
\hline \multicolumn{3}{|l|}{ DLCO, $\%$ predicted } \\
\hline Anatomic segments counting & -31 to 27 & -26 to 19 \\
\hline PS & -34 to 27 & -32 to 25 \\
\hline Volumetric CT & -17 to 15 & -13 to 13 \\
\hline \multicolumn{3}{|l|}{$\mathrm{VO}_{2}$ peak, $\mathrm{mL} / \mathrm{kg} / \mathrm{min}$} \\
\hline Anatomic segments counting & -4.74 to 5.27 & -5.21 to 2.54 \\
\hline PS & -6.96 to 5.80 & -6.72 to 3.86 \\
\hline Volumetric CT & -4.29 to 4.59 & -3.21 to 1.78 \\
\hline \multicolumn{3}{|l|}{$\mathrm{VO}_{2}$ peak, $\%$ predicted } \\
\hline Anatomic segments counting & -27 to 29 & -20 to 9 \\
\hline PS & -32 to 26 & -32 to 18 \\
\hline Volumetric CT & -21 to 22 & -14 to 8 \\
\hline
\end{tabular}

$F V C$, Forced vital capacity; $P S$, pulmonary scintigraphy; $C T$, computed tomography; $F E V_{1}$, forced expiratory volume in 1 second; $D L C O$, lung diffusing capacity of carbon monoxide; $\mathrm{VO}_{2}$, oxygen uptake.

TABLE E4. Evaluation of the volumetric computed tomography-derived multivariable regression equations to predict postoperative lung function values with respect to the measured postoperative function in patients from the validation cohort

\begin{tabular}{|c|c|c|c|}
\hline Parameter & Pearson correlation coefficient $(95 \%$ CI $)$ & Intraclass correlation coefficient $(95 \%$ CI) & Limits of agreement \\
\hline FVC, 1 & $0.955(0.918-0.976)$ & $0.949(0.908-0.972)$ & -0.46 to 0.62 \\
\hline FVC, $\%$ predicted & $0.905(0.830-0.948)$ & $0.895(0.815-0.942)$ & -14 to 18 \\
\hline $\mathrm{FEV}_{1}, 1$ & $0.953(0.914-0.974)$ & $0.952(0.913-0.974)$ & -0.29 to 0.45 \\
\hline $\mathrm{FEV}_{1}, \%$ predicted & $0.909(0.837-0.950)$ & $0.908(0.836-0.949)$ & -11 to 15 \\
\hline $\mathrm{DLCO}, \mathrm{mmol} / \mathrm{min} / \mathrm{kPa}$ & $0.859(0.753-0.922)$ & $0.859(0.754-0.921)$ & -1.27 to 1.19 \\
\hline DLCO, $\%$ predicted & $0.812(0.677-0.894)$ & $0.812(0.678-0.894)$ & -16 to 16 \\
\hline $\mathrm{VO}_{2}$ peak, $\mathrm{mL} / \mathrm{kg} / \mathrm{min}$ & $0.875(0.712-0.948)$ & $0.874(0.718-0.947)$ & -2.8 to 2.4 \\
\hline $\mathrm{VO}_{2}$ peak, $\%$ predicted & $0.962(0.907-0.985)$ & $0.963(0.912-0.985)$ & -14 to 12 \\
\hline
\end{tabular}

$\mathrm{CI}$, Confidence interval; $\mathrm{FVC}$, forced vital capacity; $\mathrm{FEV}$, forced expiratory volume in 1 second; $\mathrm{DLCO}$, lung diffusing capacity of carbon monoxide; $\mathrm{VO}_{2}$, oxygen uptake. 